\title{
PENGOLAHAN BUMBU PECAL SEBAGAI STOK BAHAN MAKANAN SAAT PANDEMI COVID 19
}

\author{
Masdania Zurairah1 ${ }^{1 *}$, Abdul Azis Syarif ${ }^{2}$, Muhammad Adam ${ }^{3}$, Budhi Santri Kusuma ${ }^{4}$ \\ ${ }^{1,2}$ Teknik Industri, Fakultas Teknik, Universitas Al-Azhar, Jl. Pintu Air IV No.214, Kwala Bekala, \\ Kec. Medan Johor, Kota Medan, Sumatera Utara 20143 \\ ${ }^{3}$ Teknik Elektro, Fakultas Teknik, Universitas Muhammadiyah Sumatera Utara, Jl. Kapten Muchtar \\ Basri No.3, Glugur Darat II, Kec. Medan Tim., Kota Medan, Sumatera Utara 20238 \\ ${ }^{4}$ Teknik Industri, Fakultas Teknik, Universitas Medan Area, Jalan Kolam Nomor 1 Medan Estate / \\ Jalan Gedung PBSI, Medan 20223
}

*masdaniazurairahsiregar64@gmail.com

\begin{abstract}
ABSTRAK. Kegiatan ini bertujuan untuk menyediakan stok makanan yang tahan lama sampai 3 minggu di udara bebas dan jika dalam kulkas akan tahan sampai 3 bulan. Jadi pada saat pandemi covid 19 saat ini dimana kita mengurangi kegiatan aktivitas di luar rumah maka bumbu pecal merupakan solusi yang sangat tepat dan berperan untuk kita sediakan sebagai stok campuran nasi. Rumah Tahfidz Khalifah Aulia yang merupakan anak tahfiz penghafal Al Quran yang terdiri dari anak santri yang berumur antara 19-21 tahun. dimana dengan adanya persediaan makanan bumbu pecal sebagai stok tambahan makanan nasi sangat memudahkan dan menguntungkan untuk tetap ada dalam persediaan makanan mereka. Bumbu pecal yang terdiri dari kacang tanah, gula merah dan rempah bawang putih dan kencur sangat baik untuk tubuh. Kandungan bumbu pecal telah lengkap kandungan nutrisinya dimana telah mengandung protein nabati dari kacang tanah, karbohidrat dari gula merah serta kandungan organosulfur dari bawang putih dan mineral dari kencur. Harga bahan yang digunakan untuk pembuatan bumbu pecal juga terbilang sangat murah dan pembuatannya juga sangat mudah namun menghasilkan bahan konsumsi bumbu pecal yang sangat enak dan gurih. Bumbu pecal dalam kegiatan pengabdian ini mengandung 3 rasa yaitu sangat pedas, pedas dan sedang. Bumbu pecal dibuat masing masing rasa sebanyak 3 $\mathrm{kg}$. Dengan membuat bahan pecal $3 \mathrm{~kg}$ kacang tanah yang rasa pedas akan menghasilkan 4,5 $\mathrm{kg}$ bumbu pecal.
\end{abstract}

Kata kunci: Bumbu pecal, Stok makanan, Pandemi covid-19

\begin{abstract}
This activity aims to provide food stocks that last up to 3 weeks in the open air, and if in the refrigerator, it will last up to 3 months. Pecal seasoning tastes very good, savory, and there is no boredom to consume it every day, very suitable for making food supplies stock. So at the time of the current covid 19 pandemics where we reduce activities outside the home, the pecal seasoning is a very appropriate solution and plays a role for us to provide as a stock of rice mixture. The house of Tahfidz Khalifah Aulia who is a child of tahfiz who memorized the Koran consisting of santri children aged between 19-21 years, wherewith the availability of pecal seasoning food as an additional stock of rice food, it is very easy and profitable to keep them in their food supply. Pecal seasoning consisting of peanuts, brown sugar and garlic, and kencur spices is very good for the body. The content of the pecal seasoning has complete nutritional content, which contains vegetable protein from peanuts, carbohydrates from brown sugar, and organosulfur range from garlic and minerals from kencur. The price of the ingredients used for making pecal seasoning is also reasonably low, but it produces delicious and savory ingredients for the consumption of pecal herb. Pecal seasoning contains 3 flavors, namely very spicy, spicy and medium. Pecal seasoning is made of $3 \mathrm{~kg}$ each. By making pecal ingredients, $3 \mathrm{~kg}$ of spicy peanuts will produce $4.5 \mathrm{~kg}$ of spicy pecal seasoning.
\end{abstract}

Keywords: Pecal seasoning, Food stock, Covid-19 pandemic

\section{PENDAHULUAN}

Mobilitas sumber daya IPTEK Nasional menjadi sangat penting, oleh karena terbatasnya sumber daya tersebut dan besarnya tantangan Bangsa yang perlu dijawab melalui pembangunan dan pengembangan IPTEK. (Siregar \& Ningsih, 2019).

Rumah Tahfiz Khalifah Aulia adalah rumah tahfiz siap mukim. Anak tahfiz akan mukim selama 2 tahun sampai selesai 30 juz. Rumah 
Tahfiz Khalifah Aulia berkedudukan di Jl. Denai Medan. Saat pandemi covid 19 seperti saat ini sangat perlu untuk menjaga agar interaksi dikurangi untuk keluar rumah. Peserta anak tahfiz Khalifah Aulia pesertanya ada 15 orang dengan seorang ustazah yang tinggal di Rumah Tahfiz Khalifah Aulia. Permasalahan yang dihadapi agar dalam kondisi saat ini disaat kita jangan terlalu banyak beraktivitas diluar rumah maka untuk penyediaan bahan makanan sebagai campuran lauk nasi, maka alternatif penyediaan stok bumbu pecal dan memkonsumsi bumbu pecal adalah solusi yang sangat praktis, mudah dan enak, cara pembuatannya mudah sehingga tidak banyak waktu untuk melaksanakannya, murah bahannya dan tahan lama produknya. Makanan ini juga mirip dengan gado-gado yang dibedakan dengan campuran bahan dan tekstur bumbunya (Adriani, 2012). Makanan pecel merupakan makanan yang terdiri atas irisan beberapa jenis sayuran seperti daun selada segar, tauge rebus, kol rebus, kangkung rebus dan semua bahan tersebut disiram dengan bumbu kacang yang rasanya gurih, makanan pecel ini banyak dijumpai di pulau Jawa (Aak, 1998). Dalam pelaksanaan pengabdian ini rasa bumbu pecal dibedakan dengan tiga macam rasa yaitu pedas, sedang dan kurang pedas, dimana hal ini tergantung dari banyaknya cabe yang digunakan. Ketahanannya bisa sampai 3 minggu dan jika di masukkan di kulkas bisa tahan sampai 3 bulan. Dengan pengembangan cara ini diharapkan kekawatiran akan lauk makanan tidak terjadi, karena stok kesediaan bumbu pecal telah ada. Kandungan bumbu pecal sebagai stok makanan telah cukup kandungannya baik segi protein, lemak, karbohidrat serta mineral. Dengan adanya bahan bumbu seperti bawang putih dan kencur dalam bahan bumbu pecal sangat baik untuk mengeluarkan angin dari badan yang sangat baik dimasa covid 19 seperti saat ini. Dengan terjunnya pengabdian masyarakat dosen Universitas Al Azhar dan Universitas Muhammadiyah Sumatera Utara ke rumah Tahfiz Khalifah Aulia akan membawa wawasan dan terwujudnya Kawasan Rumah Pangan nantinya serta akan mengurangi biaya bulanan dalam hal transportasi, karena adanya stok bumbu pecalnya yang telah tersedia tidak keluar setiap saat seperti sebelum adanya stok bumbu pecal atau sebelum adanya pelaksanaan pengabdian masyarakat. Anak tahfiz kegiatan untuk mencari makanan uda berkurang, sehingga berefek kepada besarnya pengeluaran untuk kebutuhan pangan anak tahziz Khalifah Aulia. Selanjutnya anak tahfiz Khalifah Aulia juga dilatih untuk berbisnis bumbu pecal, agar kelak bisa berbisnis. Tujuan dari program pengabdian masyarakat ini adalah

1. Meningkatkan pengetahuan dan ketrampilan, kesadaran serta memotivasi anak tahfiz Khalifah Aulia dalam penyediaan stok bahan makanan yang dalam hal ini bumbu pecal.

2. Menerapkan beberapa teknik sederhana cara pengolahan bumbu pecal secara mudah oleh anak tahfidz Khalifah Aulia. Metode kegiatan yang dilakukan adalah diskusi dan demonstrasi praktik langsung di lokasi rumah tahfiz Khalifah Aulia.

3. Melaksanakan evaluasi awal sebagai landasan untuk menentukan posisi pengetahuan kelompok mengenai pemanfaatan bahan bumbu pecal selanjutnya jika telah terpenuhi untuk menerapkan bisnis bumbu pecal yang diusahakan secara online, melalui penerapan konsep Kawasan Rumah Tahfiz Khalifah Aulia Kejuruan yang dalam hal ini penyediaan bahan makanan bumbu pecal.

Pelaksanaan bumbu pecal yang akan dilakukan dalam hal ini terletak dengan perbedaan rasa pedas dengan perbedaan banyak cabai dan jenis cabai yang digunakan yaitu cabai rawit dan cabai merah. Pembuatan ras pedas dengan perbandingan cabai merah cabai rawit adalah 1,5 ons : 1,5 ons. Perbandingan Rasa dalam hal ini pedas dengan jumlah cabai rawit 1,5 ons dan cabai merah I ons. Rasa dengan rasa pedas dengan perbandingan cabai merah: cabai rawit $=1$ ons : 1 ons dan rasa kurang pedas dengan hanya menggunakan cabai merah sebanyak 0,5 ons tanpa menggunakan cabai rawit. Dengan terlaksananya pengabdian masyarakat ini pengembangan stok bumbu pecal dan ketersediaan bumbu pecal yang telah ada di rumah tahfiz Khalifah Aulia maka penerapan bisnis juga akan dikembangkan agar anak tahfiz mempunyai keterampilan., Akhir dari bumbu pecal ini juga dimanfaatkan untuk pengembangan stok untuk segi bisnisnya. Hasil bumbu pecal yang diperoleh selanjutnya dikemas dengan berat bumbu pecal 1 ons setiap bungkusnya, dimana dalam $1 \mathrm{~kg}$ bumbu pecal dengan berat 1 ons akan menghasilkan 15 bungkus. 


\section{METODE}

Alat

Alat yang digunakan adalah kompor gas, kuali, sendok goreng, saringan, panci, timbangan, plastik seperempat, hekter, meja, steling.

\section{Bahan}

Bahan yang digunakan dalam pengabdian ini adalah kacang tanah $3 \mathrm{~kg}$, gula 1,5 kg, bawang putih 3 ons, kencur 3 ons, Minyak goreng daun jeruk purut dan garam.

\section{Lokasi Pengabdian Masyarakat}

Pengabdian masyarakat dilaksanakan oleh dosen Universitas Al Azhar dan Universitas Muhammadiyah Sumatera Utara yang lokasinya di rumah tahfiz Khalifah Aulia yang beralamat Jl. Denai Medan, kecamatan Medan Denai, kelurahan Tegal Sari Mandala.

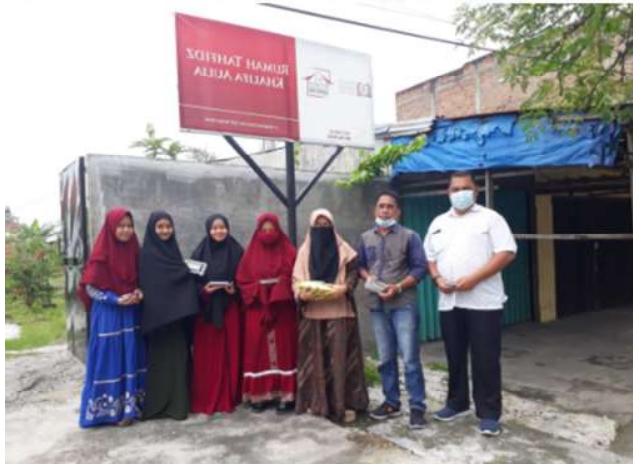

Gambar 1. Lokasi Kegiatan Pengabdian Masyarakat

\section{Prosedur dan Bahan Penyimpan}

Sebanyak $3 \mathrm{~kg}$ bahan kacang tanah di timbang dan selanjutnya di bersihkan dari kotoran lalu ditiriskan, bawang putih dan kencur masing masing 3 ons di kupas selanjutnya dicuci. Ketiga bahan ini di goreng masing masing dengan api kecil. Selanjutnya rasa pedas digunakan perbandingan cabai rawit 1,5 ons dan cabai merah 1,5 ons cabai merah lalu dibersihkan dan siap untuk digoreng. Selanjutnya ditimbang gula merah sebanyak $1,5 \mathrm{~kg}$. Bahan selanjutnya diiris dan jeruk purut sebanyak 45 lembar dan asam jawa sebanyak 0,5 ons. Seperti Gambar 2 . sendok, Kertas

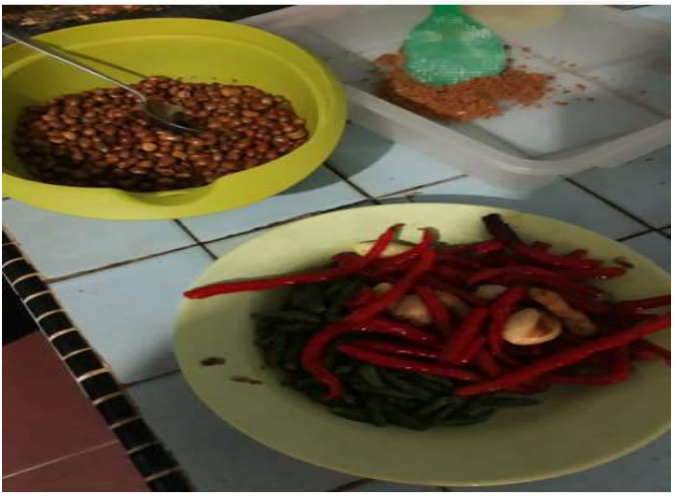

Gambar 2 Bahan Bumbu Yang Telah Digoreng

Selanjutnya bahan yang telah digoreng cabai rawit, cabai merah digiling dan ditambah garam. Setelah halus digiling bawang putih, kencur setelah halus digiling daun jeruk purut, lalu disisihkan. Selanjutnya dihaluskan kacang tanah, Setelah halus kacang tanah digabung dengan bahan bumbu. Selanjutnya ditambah gula merah sebanyak $1,5 \mathrm{~kg}$. Seperti gambar 3

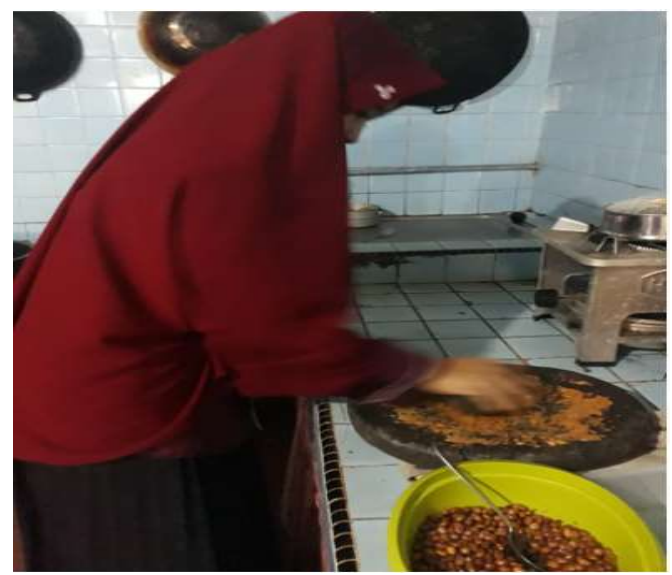

Gambar 3. Penggilingan Bahan Bumbu Pecal

Setelah bumbu semua halus lalu disisihkan, selanjutnya proses penghalusan kacang yang telah digoreng. Setelah dingin kacangnya lalu dihaluskan. Gambar 4..

- Setelah kacang tanah halus lalu dicampur dengan bumbu halus pecal yang telah halus, sampai tercampur semua. Terakhir yang kita tambahkan adalah gula merah.

- Hasilnya setelah halus adalah bumbu pecal yang enak.

- Selanjutnya bumbu pecal di timbang dan selanjutnya dikemas dalam plastik

- Setelah dikemas dengan rapi selanjutnya adalah proses pelabelan nama bumbu pecal yang Bernama bumbu pecal Rumah Tahfiz Khalifah Aulia (RT. Khalifah Aula)

29|P a g e 


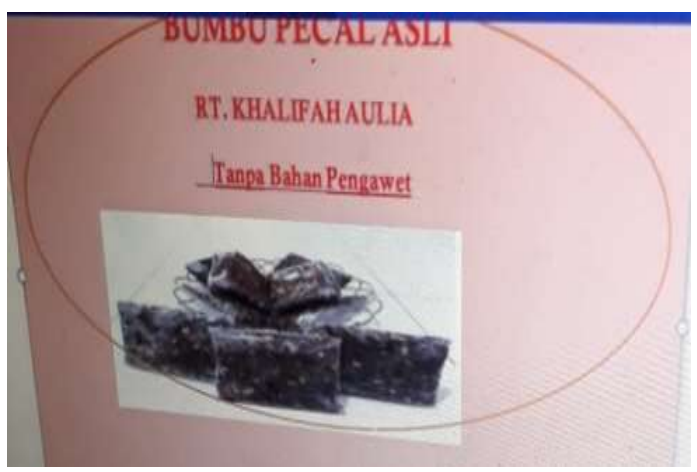

Gambar 4. Proses Pelabelan

\section{Penyediaan Stok Bumbu Pecal}

Bumbu pecal yang telah selesai dikemas dimasukkan dalam steling penyimpanan stok bumbu pecal.

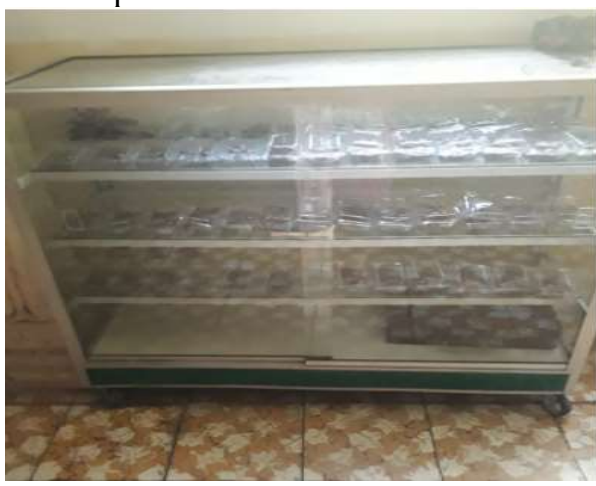

Gambar 5. Steling Tempat Penyimpanan Stok Bumbu Pecal

\section{HASIL DAN PEMBAHASAN}

Rasa bumbu pecal yang paling disukai dan paling diminati anak tahiz adalah rasa bumbu pecal yang sangat pedas yaitu sebesar $60 \%$, rasa pedas $25 \%$ dan rasa kurang pedas $15 \%$.

Tabel 1. Perbandingan rasa bumbu pecal

\begin{tabular}{lllll}
\hline No & Bahan & $\begin{array}{l}\text { Sangat } \\
\text { Pedas }\end{array}$ & Pedas & $\begin{array}{l}\text { Kurang } \\
\text { Pedas }\end{array}$ \\
\hline 1. & Kacang & $1 \mathrm{~kg}$ & $1 \mathrm{~kg}$ & $1 \mathrm{~kg}$ \\
\hline 2. & $\begin{array}{l}\text { Gula } \\
\text { Merah }\end{array}$ & 2,5 ons & 2,5 ons & 2,5 ons \\
\hline 3. & $\begin{array}{l}\text { Cabai } \\
\text { Rawit }\end{array}$ & 1,5 ons & 0,5 ons & - \\
\hline 4. & $\begin{array}{l}\text { Cabai } \\
\text { Merah }\end{array}$ & 1,5 ons & 1 ons & 1 ons \\
\hline 5. & $\begin{array}{l}\text { Bawang } \\
\text { Putih }\end{array}$ & 0,5 ons & 0,5 ons & 0,5 ons \\
\hline 6. & Kencur & 0,5 ons & 0,5 ons & 0,5 ons \\
\hline
\end{tabular}

\begin{tabular}{lllll} 
7. & $\begin{array}{l}\text { Daun } \\
\text { Jeruk } \\
\text { Purut }\end{array}$ & $\begin{array}{l}15 \\
\text { lembar }\end{array}$ & $\begin{array}{l}15 \\
\text { lembar }\end{array}$ & $\begin{array}{l}15 \\
\text { lembar }\end{array}$ \\
8. & $\begin{array}{l}\text { Asam } \\
\text { Jawa }\end{array}$ & $\begin{array}{l}3 \\
\text { bungkus }\end{array}$ & $\begin{array}{l}3 \\
\text { bungkus }\end{array}$ & $\begin{array}{l}3 \\
\text { bungkus }\end{array}$ \\
\hline
\end{tabular}

Dari tabel mudah terlihat bahwa rasa sangat pedas, rasa pedas dan kurang pedas terletak pada perbandingan banyaknya cabai rawit dan cabai merah yang digunakan.

Tabel 2. Persentase rasa yang disukai

\begin{tabular}{lll}
\hline No & Rasa Bumbu Pecal & $\%$ \\
\hline 1. & Rasa sangat pedas & 55 \\
\hline 2. & Rasa pedas & 30 \\
\hline 3. & Rasa kurang pedas & 15 \\
\hline
\end{tabular}

\section{SIMPULAN}

Adapun kesimpulan dari kegiatan tersebut yaitu

1. Dengan adanya stok bumbu pecal di rumah tahfidz Khalifah Aulia pada saat pandemi covid 19 ini sangat berperan untuk mengurangi aktivitas anak tahfidz keluar rumah.

2. Bumbu pecal sebagai stok yang disimpan dalam kemasan plastik tahan sampai 3 minggu di udara terbuka dan tahan 3 bulan bumbu pecal jika disimpan dalam kulkas.

3. Pengolahan dan persediaan stok bumbu pecal dilakukan setiap satu kali dalam satu bulan pada saat anak tahfidz. libur aktivitasnya

4. Dengan adanya bumbu pecal dengan 3 rasa maka yang paling disukai anak tahfidz adalah yang rasa sangat pedas dengan perbandingan cabai rawit dan cabai merah sebesar 4,5 ons:4,5 ons dengan kacang 3 $\mathrm{kg}$. 


\section{DAFTAR PUSTAKA}

Aak, 1998, Kacang Tanah, Kanisius, Yogyakarta

Adriani, $\quad$ Merryana, Dr.; Wirajatmadi,Bambang, Prof. 2012. Pengantar gizi masyarakat. Jakarta: Kencana

Afa laode. 1998. Pengaruh Varietas, Ukuran Benih dan Pemupukan dan Ca terhadap Hasil dan Mutu Benih Kacang Tanah (arachis hypogaea $\mathrm{L}$ ).

Andrianto, TT. Dan N. Indarto, 2004.Budidaya dan Analisis Usaha Tani Kedelai, Kacang Hijau,Kacang Panjang, Absolut, Yogyakarta

Astawan, Made. 2009. Sehat dengan Hidangan Kacang dan Biji-bijian. Jakarta: Penebar Swadaya

Direktorat Budidaya Kacang-kacangan dan Umbi-umbian2008.

Ginting, E.2010. Petunjuk Teknis Produk Olahan Kedelai (Materi Pelatihan Agribisnis bagi KMPH). Balai penelitian Kacang-kacangan dan Umbi

Siregar, Z. H., \& Ningsih, M. S. (2019). Implementasi metode NIOSH dan analisa QEC pada alat potong ranting. Operations Excellence: Journal of Applied Industrial Engineering, 11(1), 34-48.

https://doi.org/10.22441/oe.v11.1.201

9.014 